\title{
МОТИВАЦИЯ КАК АКМЕОЛОГИЧЕСКОЕ УСЛОВИЕ СТАНОВЛЕНИЯ РОДИТЕЛЬСКОЙ ИДЕНТИЧНОСТИ
}

\section{MOTIVATION AS THE ACMEOLOGICAL CONDITION OF FORMATION OF PARENTAL IDENTITY}

\author{
Yu. Chistyakova \\ V. Tsapova
}

Summary: This publication reviews: a) relevance of the research the concept of «identity»; b) a survey of the research of the concept of «identity» in foreign and domestic psychological science; c) definition of professional identity in the mainstream of acmeology; d) parental identity in the context of personal or family identity; e) conscious parenthood as a phenomenon of a sociocultural environment.

As a result of the research, the concept of "parental identity» as the formed image of oneself as a parent through a system of appropriate values, attitudes, norms of parental behavior. The process of formation of the parental identity through the system of components (motivational, cognitive, affective, behavioral) has been analyzed. A definition of "conscious parenthood» is given. The role of motivation in achieving a parent's acme is described. The groups of motives that make up the motivational component of the parental identity are singled out.

Keywords: identity, professional identity, parental identity, motivation, motives, components of parental identity, conscious parenthood, acme parent.
Чистякова Юлия Сергеевна

аспирант, Калужский государственный университет имени К.Э. Циолковского chistyakovays@yandex.ru

Цапова Виктория Григорьевна аспирант, Калужский государственный университет имени К.Э. Циолковского toruchka@mail.ru

Аннотация: В данной публикации рассмотрены: а) актуальность исследования понятия «идентичность»; б) обзор исследований понятия «идентичность» в зарубежной и отечественной психологической науке; в) определение профессиональной идентичности в русле акмеологии; г) родительская идентичность В контексте личностной или семейной идентичности; д) осознанное родительство как феномен социокультурной среды.

В результате исследования определено понятие «родительская идентичность» как сформированный образ себя в качестве родителя через систему соответствующих ценностей, установок, норм родительского поведения. Проанализирован процесс становления родительской идентичности через систему компонентов: мотивационного, когнитивного, аффективного, поведенческого. Дано определение понятию «осознанное родительство». Описана роль мотивации при достижении акме родителя. Выделены группы мотивов, составляющие мотивационный компонент родительской идентичности.

Ключевые слова: идентичность, профессиональная идентичность, родительская идентичность, мотивация, мотивы, компоненты родительской идентичности, осознанное родительство, акме родителя.

Идентичность - это понятие (категория) социально-гуманитарных наук, применяемая для описания индивидов и групп в качестве «относительно устойчивых целостностей, тождественных самим себе» [5].

Исходя из данного определения видно, что идентичность, скорее, рассматривается не как свойство, присущее индивидам и группам, а как некое субъективное отношение, которое формируется в процессе их (индивидов и групп) взаимодействия. Таким образом, идентичность следует понимать как самоопределение индивида в его исторической обусловленности и культурно-контекстной детерминации.

В связи с этим становится актуальным проведение теоретического обзора рассмотрения понятия «идентичность» в отечественной и зарубежной психологической науке прошлого и нынешнего века.

\section{Понятие «ицентичность»}

Одним из первых вопросу идентичности уделил внимание Э. Эриксон, который в своей работе «Иден- 
тичность: юность и кризис» рассматривал ряд психосоциальных кризисов, которые переживает индивид на протяжении всей жизни. Там же он упоминает о чувстве идентичности как о неком субъективном переживании непрерывной самотождестенности, выражающемся в интенсивном и глубоком «ощущении собственной активности и жизненной силы» [12].

Э. Эриксон считал, что именно в подростковом возрасте у индивида формируется «психическая целостность» как некое субъективное ощущение, чувство внутренней идентичности, с помощью которого человек способен проследить временные связи между самоощущением в прошлом, настоящем и будущем, а также собственным представлением о себе, соотносимым с взглядами о себе других людей [12].

В то же время ряд других авторов, среди которых представители зарубежной психологии (Р. Мейли, Г. Олпорт, К. Роджерс, Х. Салливен, Ю. Хабермас, А. Гидденс) и отечественной психологии (К.А. Абульханова-Славская, М.М. Бахтин, Э.В. Ильенков, И.С. Кон, А.Н. Леонтьев, С.Л. Рубинштейн, А.Г. Спиркина) в своих работах так или иначе также обращается к исследованию проблематики идентичности.

Среди зарубежных авторов, исследующих данную проблематику, достаточно известен Дж. Марсиа, который определял идентичность как структуру эго, как внутреннюю самосоздающуюся динамическую организацию потребностей, способностей, убеждений и индивидуальной истории [9].

В отечественной психологии одним из первых, кто затронул данную проблематику в своих исследованиях, был И.С. Кон. Он рассматривал идентичность как условный конструкт личности, который содержит динамические мотивационные тенденции, уравновешивающие внешние и внутренние импульсы [4].

В рамках акмеологии подробно рассматривается профессиональная идентичность, что находит своё отражение в трудах Е.П. Ермолаевой, Н.Л. Ивановой, Е.Н. Кирьяновой, Е.В. Коневой, Т.В. Мищенко, Ю.П. Поваренкова, Л.Б. Шнейдер и др.

Так Л.Б. Шнейдер рассматривает профессиональную идентичность сквозь призму психолого-педагогической проблематики. Автор высказывает мнение о том, что идентичность является результатом активного процесса, отражающего представления субъекта о самом себе, собственном пути развития [11].

В свою очередь И.В. Брестер определяет профессиональную идентичность как некий «образ Я-профессионала», устойчивый во времени и являющий- ся результатом «сформированной системы профессиональных установок и ценностей» [1].

В данной работе мы будем рассматривать такое понятие, как «родительская идентичность», которое на сегодняшний день является достаточно скромно изученным, что объясняется, во многом, некоторой противоречивостью его конструкта и многозначностью трактовки.

\section{Определение родительской идентичности}

Как правило, родительская идентичность рассматривается в контексте личностной идентичности. Это можно обнаружить в работах Ю.В. Борисенко, О.С. Донцовой, А.Н. Елизарова, И.С. Морозовой, Г.Т. Хоментаускаса.

К примеру, В.Р. Орестова при исследовании идентичности подростков в области семьи и семейных взаимоотношений определила в качестве показателя достигнутой идентичности осознанно созданную субъективную модель семьи на основе анализа собственной родительской семьи [7].

Другими исследователями (Н.В. Лукьянченко, О.А. Минеевой, Е.А. Савковой) родительская или семейная идентичность понимается как образ родителя через систему значений, которые используются для восприятия не только окружающего мира, но и, прежде всего, себя внутри семьи и себя в качестве родителя [6].

В работах Т.А. Гурко, Е.И. Захаровой, И.С. Кона, Г.Г. Филипповой отмечается, что родительскую идентичность следует рассматривать в связи с наступлением родительства, которое, в свою очередь ведёт за собой изменения в личности взрослых людей [10].

Мы будем понимать родительскую идентичность как сформированный образ себя в качестве родителя через систему соответствующих ценностей, установок, норм родительского поведения.

Действительно, становление родительской идентичности - процесс, зачастую, длительный, требующий соответствующих условий.

Е.И. Захарова, Ю.А. Торчинова при исследовании условий становления материнской идентичности определили её взаимосвязь с характером ценностной направленности женщин. Речь идёт, прежде всего, о направленности на ребёнка [2].

\section{Компоненты родительской идентичности}

На наш взгляд, становление родительской идентичности следует рассматривать через систему развития следующих компонентов: 


\section{- мотивационного, \\ - когнитивного, \\ - арфективного (реслексивного), \\ - поведенческого.}

Мотивационный компонент родительской идентичности включает в себя ценностные ориентиры родителя, включает образ Я-родителя и характеризуется направленностью на ребёнка и на семью, обладающих безусловной ценностью.

Когнитивный компонент родительской идентичности в своей основе базируется на сформированных представлениях индивида о себе как о родителе. Формирование данных представлений во многом будет зависеть от собственной родительской среды, из которой вышел тот или иной индивид, присвоив себе конкретные образы, стереотипы, установки, паттерны будущей родительской идентичности.

Аффективный (рефлексивный) компонент родительской идентичности способствует формированию эмоциональной оценки себя в качестве родителя на предмет соответствия уже сформированным паттернам родительства.

Поведенческий компонент родительской идентичности включает соответствующие действия, акты, направленные на удовлетворение базовых потребностей ребёнка, реализующие различные формы родительского поведения, адекватные запросам ребёнка и непротиворечащие собственным представлениям о родительстве.

Ведущую роль здесь играет мотивационный компонент, являясь неким движущим фактором для развития последующих компонентов в то же время развивающийся параллельно с ними. Обладая такой двоякой функцией, мотивация способствует формированию осознанного родительства через становление родительской идентичности.

Рассматривая процесс становления как деятельностный, следует отметить, что деятельность, по А.Н. Леонтьеву, характеризуется иерархической системой мотивов, в том числе, смыслообразующих и побудительных [3]. В процессе становления родительской идентичности оба вида мотивов могут выступать как единое целое. Способствуя формированию ценностного отношения к ребёнку, к себе как к родителю (смыслообразующая часть), одновременно мотив выступает в качестве стимула к осуществлению осознанной родительской деятельности (побудительная часть).

На наш взгляд, становление родительской идентичности можно представить в виде вектора акме, движение к вершине которого будет являться стремлением к формированию осознанного родительства. Рассмотрим данное понятие.

Осознанное родительство - это психологическое явление, базирующееся на сформированных родительских ценностях, характеризующееся позитивным восприятием себя в качестве родителя и выражающееся в адекватном родительском поведении.

Как феномен, осознанное родительство характеризуется процессуальностью и динамичностью. Особую роль в его формировании играет родительская идентичность. Каждый из вышеназванных компонентов родительской идентичности в совокупности способствует движению к вершине акме осознанного родителя.

В качестве акмеологического условия такого движения выступает, прежде всего, мотивация, включающая ряд мотивов:

- мотивы деятельности, как совокупность внутренних и внешних условий, побуждающих родителей к проявлению активности и совершению действий, обусловленных родительскими чувствами, ценностями, установками, характеризующимися выполнением родительских функций в контексте родительского поведения адекватного той или иной ситуации;

- мотивы ценностного отношения к ребёнку, формирующиеся в контексте социально-культурной обусловленности, характеризующиеся направленностью на ребёнка и способствующие не только удовлетворению его потребностей и желаний (биологическая составляющая), но и восприятию его как отдельного индивида, личности (социальная составляющая);

- мотивы ценностного отношения к родителю, формирующиеся в контексте социально-культурной и психолого-педагогической обусловленности. Данный вид мотивов способствует формированию позитивной самооценки родителя.

Мотивы деятельности, таким образом, отвечают за побудительную часть, а мотивы ценностного отношения к ребёнку и к родителю будут составлять смыслообразующую часть мотивационного компонента процесса становления родительской идентичности.

Таким образом, мы рассмотрели процесс становления родительской идентичности через систему компонентов, в которой ведущую роль играет мотивационный компонент, в свою очередь, состоящий из группы мотивов, обладающих побудительной и смыслообразующей характеристиками. Становление родительской идентичности запускает движение к вершине акме осознанного родительства. 


\section{ЛИТЕРАТУРА}

1. Брестер И.В. Методологические основы создания акмеологического пространства становления профессиональной идентичности студентов// Проблемы современной науки и образования, 2015. № 34.

2. Захарова Е.И., Торчинова Ю.А. Условия становления материнской идентичности//. Известия ПГПУ им. В.Г. Белинского, 2012. № 28. С. $1234-1239$.

3. Карабанова 0.А. Психология семейных отношений и основы семейного консультирования: Учебное пособие. - М.: Гардарики, 2005. - 320 с.

4. Кон И.С. Открытие «Я» / И.С. Кон. - М., 2008. - 367 с.

5. Малахов В.С. Идентичность // Новая философская энциклопедия. - М.: Мысль, 2001. Т. 3. - 692 с.

6. Минеева О.А. Возрастные и гендерные особенности содержания имплицитных теорий семьи. Автореф. дисс. .. канд. психол. наук. М.: МГУ, 2011. - 35 с.

7. Орестова В.Р. Формирование личностной идентичности в старшем подростковом и юношеском возрасте: дисс... канд. психол. наук. М., $2001 .-178$ с.

8. Розин В.М. Гуманистическая идентичность как форма проявления идентификации и как фасад и прикрытие нового эгоизма / В.М. Розин// Мир психологии: Научно-методический журнал / Ред. Д. И. Фельдштейн. - 2012. - №1 (69) январь-март 2012. - с.195-203.

9. Татарко С.А. Измерение идентичности в рамках статусной модели Дж. Марсиа // психологическая диагностика, 2009. № 1. - С. 1-39.

10. Филиппова Г.Г. Психология материнства: Учебное пособие. - М.: Изд-во Института Психотерапии. 2002. - 240с.

11. Шнейдер Л.Б. Профессиональная идентичность: Монография. М.: МОСУ, 2001 г. 272 с.

12. Эриксон Э. Идентичность: юность и кризис. Пер. с англ. - М.: Флинта, 2006. - 342 с.

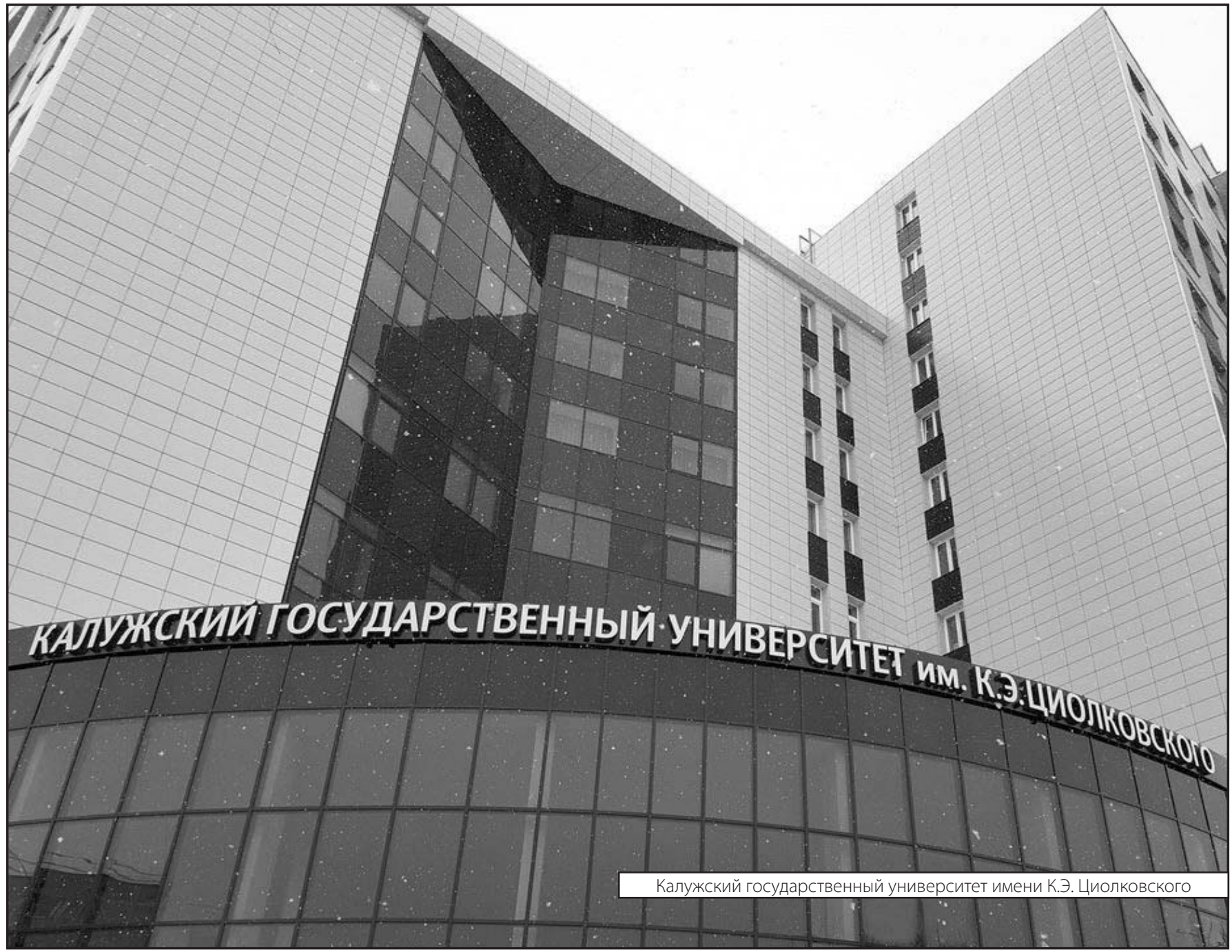

